\title{
Pleistocene to Recent tectonics in the Rhenish Massif (Germany)
}

\author{
W. Meyer ${ }^{1,2} \&$ J. Stets ${ }^{1}$ \\ 1 Geologisches Institut der Universität Bonn, Nussallee 8, D - 53115 Bonn, Germany \\ 2 corresponding author; e-mail: geo-sek@uni-bonn.de
}

Manuscript received: August 2000; accepted: January 2002

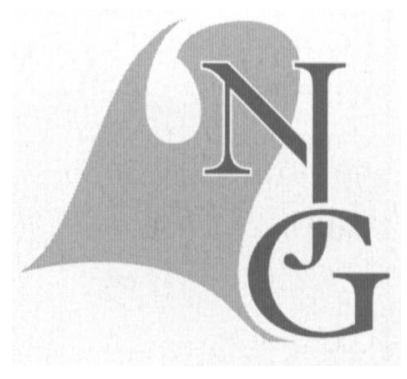

\begin{abstract}
Uplift of the Rhenish Massif can be demonstrated by means of the stream-made river terrace system that accompanies the Rhine river and its tributaries along their way through or within this part of the Variscan fold and thrust belt. The height difference between a former valley floor, especially that of the Younger 'Hauptterrasse' (Main Terrace), and the recent one allows to quantify the uplift by the amount of downcutting erosion. The uplift velocity increased just after the BRUNHES / MATUYAMA boundary, i.e. about $0.8 \mathrm{Ma}$ B.P. Since that time, a domal uplift of more than $250 \mathrm{~m}$ is documented in the eastern Hunsrück and in the south-eastern Eifel. The area of this maximum height anomaly is situated just between the Eastand West-Eifel Quaternary volcanic districts. Thus, causal connections are supposed. The domal uplift is affected by normal faulting partly inherited since Tertiary rifting.
\end{abstract}

Keywords: Rhenish Massif, Pleistocene, fluvial terrace system, downcutting erosion, neotectonics, domal uplift, Eifel, Hunsrück, Rhine, Mosel, Lower Rhine Basin, Neuwied Basin

\section{Introduction}

Previous research work revealed uplift in the Rhenish Massif during the Cenozoic (for detailed information see e.g. Fuchs et al., 1983). As a result of this process, the Rhine River and its tributaries were forced to cut their valleys into the substratum. It consists mainly of the Devonian with smaller areas of Carboniferous rocks. The Rhenish Massif is a part of the Rhenohercynian fold and thrust belt which was formed during the Variscan orogeny.

Interaction of Late Tertiary to recent tectonic activities with the differing young erosional processes that are caused by the heavily changing climatic conditions during the Pleistocene produced the wellknown 'valley-in-valley' fluvial terrace system (Fig. 1). The cyclic river terraces document different evolu- tionary stages of the ancient river system. Differences exist between the Pliocene as well as the Early Pleistocene original valley floors and those of Middle and Late Pleistocene to Recent age. During the older period, broad-floored valleys up to $10 \mathrm{~km}$ wide and even more existed, each with a rather flat floor. These stages are called Trough Valley (Trogtal-Stadium, Tertiary) and Plateau Valley (Hoch- or Plateautal-Stadium, Early Pleistocene). In contrast, the incised younger stages, called Canyon or Channel Valley (Engtal-Stadium), are characterised by rather narrow incisions and steep slopes. They contain relics of inclined ancient river floors near to their margins. Thus, a sudden change in fluvial activity can be derived using geomorphological criteria (Fig. 1):

(1) The ancient Trough and Plateau Valleys contain up to three Pliocene (KOT) and five to six Early 


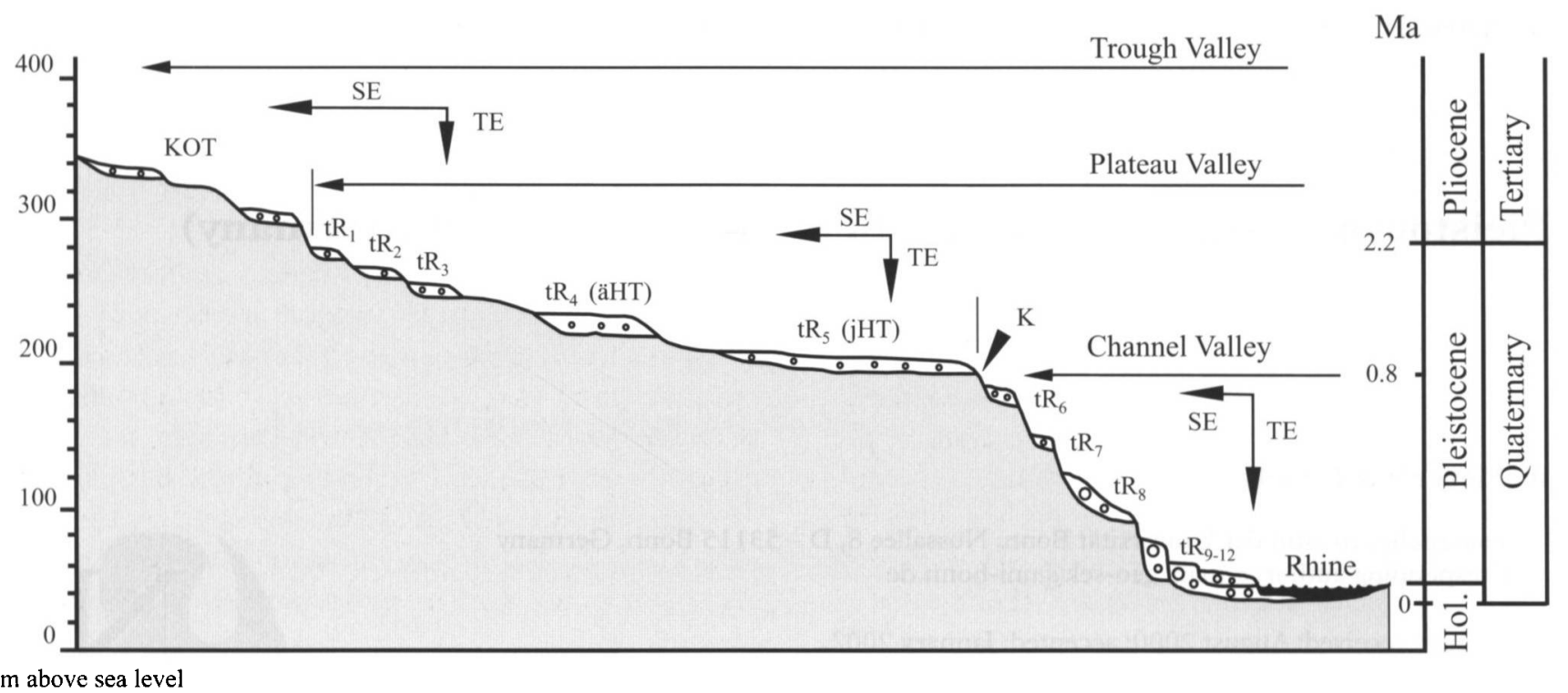

Fig. 1. Diagram of the stream-made cyclic terrace system in the Rhenish Massif as developed along the river Rhine (tR); abbreviations: SE lateral erosion, TE downcutting erosion, $\mathrm{K}$ morphological edge between Plateau Valley and incised inner Canyon, KOT Kieseloolith Terraces (Pliocene), $t_{\mathrm{R} 1-3}$ Older Pleistocene terraces, $\mathrm{tR}_{4}$ Older 'Hauptterrasse' (Main Terrace, $\ddot{\mathrm{H}} \mathrm{HT}$ ), $\mathrm{tR}_{5}$ Younger 'Hauptterrasse' $\left(\mathrm{jHT}\right.$ ), $\mathrm{tR}_{6}$ youngest unit (substage) of 'Hauptterrasse' complex, $\mathrm{tR}_{7-12}$ suite of Middle and Lower Terraces.

Pleistocene terraces $\left(\mathrm{tR}_{1-5,6}\right)$; they originated mostly from laterally cutting erosion (SE) during a period of about $4.5 \mathrm{Ma}$.

(2) In contrast, the younger Canyon or Channel Valley contains relics of six to seven terraces $\left(\mathrm{tR}_{6,7-12)}\right.$ that were formed by a predominantly downcutting erosion (TE) during the last $0.8 \mathrm{Ma}$.

There is no doubt that tectonic processes played the most important role controlling the intensity and the character of the erosion. Thus, the abrupt change from lateral (SE) to downward (TE) directed erosion is due to a change in uplift velocity. Yet, exogenic processes initiated by severe climatic changes during the Pleistocene were responsible for the formation of the different ancient river floors and their sedimentary cover.

\section{Methods}

Although plateau uplift was stated already more than hundred years ago, no attempt was made to quantify this phenomenon throughout the river systems within the Rhenish Massif. For this purpose, the sharp morphological edge between the older Plateau Valley and the incised younger Canyon (K, Fig. 1) can be considered as a rather reliable marker. Here, the last flat ancient river floor, i.e. the Younger 'Hauptterrasse' (Main Terrace, $\mathrm{jHT}, \mathrm{t}_{5}$ ), and the steep slope of the Canyon form this edge. It can be followed throughout the whole Rhenish Massif along the main rivers and their tributaries. In addition, this characteristic marker allows the correlation across faults and gaps using mapping practices in the field and in the lab. Thus, block tilting, uplift, and faulting can be derived along the river long profiles (Meyer \& Stets, 1998a).

The height difference between the floor of the Younger 'Hauptterrasse' valley ( $\mathrm{jHT}, \mathrm{t}_{5}$ ) and this of the recent river exactly shows the compensation of uplift by downcutting erosion during the last $0.8 \mathrm{Ma}$. It can be determined directly for the rivers Rhine, Mosel, Saar, and Lahn, as they all cross the Rhenish Massif. In contrast, all these smaller tributaries with their source area within the Rhenish Massif suffered from uplift. Mapping data from all of them have to be corrected. Their complete river long profiles of the Younger 'Hauptterrasse' $\left(t_{5}\right)$ have to be constructed first. Then, they must be linked to the longitudinal profile of the main river at its base level in the mouth region of the tributary (Hoffmann, 1996; Meyer \& Stets, 1998a).

North of Bonn, the Rhine enters into the Lower Rhine Basin. This region underwent subsidence along faults running northwest-southeast. It acted as a rift system since the Late Oligocene. This faulting activity along normal faults also affected the Rhenish Massif in its northern part and the river terraces there. According to the results of Ahorner (1962), these faults have been continuously active during the Pleistocene, and they are still active today. In the Lower Rhine Basin, sediments of the rivers Rhine and Meuse are interfingering with each other. They both formed a common flat fluvial flood plain in the northern foreland of the Rhenish Massif during the evolution of the 'Hauptterrasse' (Main Terrace). Correlation be- 
tween the different stages of the cyclic river terraces in both regions revealed that the Younger 'Hauptterrasse' of the Middle Rhine area ( $\mathrm{jHT}, \mathrm{tR}_{5}$ ) is equivalent to the Younger 'Hauptterrasse 3' (HT 3) in the Lower Rhine area (Schnütgen, 1974; Hoselmann, 1996). Mapping of the basis of this HT-level disclosed that the main tectonic units (Köln and Ville Block, Erft Basin and Rur Graben) have been active during the entire Pleistocene. Most of the bounding faults can be located in the longitudinal profiles along the rivers Rur, Erft, Ahr, and their tributaries. Uplift and/or subsidence within the Lower Rhine Basin can be quantified using the height difference between the recent base level of the rivers Rhine and Meuse in relation to the basis of 'Hauptterrasse 3' (HT3).

\section{Age relationships}

Using the palaeomagnetic data of Fromm (1984), the approximate age of our main tectonic marker (jHT, $t_{5}$, HT3) can be determined:

- In the Middle Rhine area, sediments and fossil soils covering the gravels of the Younger 'Hauptterrasse' ( $\mathrm{HHT}, \mathrm{tR}_{5}$ ), as well as fluvial sediments that belong to younger terraces of the Rhine and Mosel river systems show normal magnetic polarity. In contrast, older levels are mostly reverse.

- In the Lower Rhine area, fossil soils on top of the 'Hauptterrasse 3' (HT3) show normal magnetic polarity whereas silts and clays within the sedimentary package are reverse (Klostermann, 1992).

This confirms that the tectonic marker lies near to the magnetic BRUNHES / MATUYAMA boundary. According to Spell \& McDougall (1992) and others, this change in magnetic polarity occurred about $0.8 \mathrm{Ma}$ B.P. As a consequence, the acceleration of uplift which produced the marked change in valley morphology started nearly immediately or only a short time after that palaeomagnetic event. The next younger level of the terrace system, i.e. the youngest unit of the 'Hauptterrasse' system or substage of the 'Jüngere Hauptterrasse' (UjHT, tR $_{6}$, Fig. 1), already shows indications of increased downcutting erosion. Thus, it documents the beginning of the new tectonic regime, which is characterised by accelerated uplift. This opinion is in contrast to the one of Hoselmann (1996), who postulates a later start of this tectonic activity, i.e. just after this substage (post-UjHT). Yet, discussions on this topic are not finally settled until now.

On the other hand, if a maximum age of $0.8 \mathrm{Ma}$ is accepted, integral uplift or subsidence rates of different regions can be calculated.

\section{Results and discussion}

A map containing all the relevant data that have been obtained throughout the Rhenish Massif and in the southern part of the Lower Rhine Basin is given in Fig. 2.

It shows the results of the young tectonic activity during the last $0.8 \mathrm{Ma}$ using contour lines of $50 \mathrm{~m}$ in height difference between the marker edge of the jHT and the recent river floor. Observation data points are marked by dots along the rivers. This map is a completed version of the one already published by Meyer \& Stets (1998b). Especially the southern part of the Lower Rhine Basin and the adjoining areas of the Eifel Mountains now have been worked out in more detail.

The map shows a general uplift of the Rhenish Massif of about 50 to $100 \mathrm{~m}$ during the last $0.8 \mathrm{Ma}$. That means, uplift of the whole massif normally amounts to integral rates between approx. 6 and 12 $\mathrm{cm} \mathrm{ka}^{-1}$. This is obvious wherever rivers enter or leave the Rhenish Massif.

Moreover, a maximum uplift of more than $250 \mathrm{~m}$ is restricted to the area west of the river Rhine, i.e. the north-eastern Hunsrück and the northern and eastern Eifel. The area of this height anomaly extends in a NW-SE direction. The highest amount of elevation of almost $300 \mathrm{~m}$ is found in the area between Kelberg and Kaisersesch (Southeast-Eifel). Here, the integral uplift rates exceed $35 \mathrm{~cm} \mathrm{ka}^{-1}$. The area of this maximum anomaly is situated just between the Pleistocene West- and East-Eifel volcanic districts. It is a part of the huge area of increased young domal uplift trending WNW-ESE from the Ardennes to the Hunsrück area (Fig. 2). It runs just obliquely to the structures of the Variscan fold and thrust belt.

Normal faulting affected this huge domal uplift in the south-eastern continuation of the Lower Rhine Basin, in the Neuwied Basin, and in the Lower Mosel area SW of Koblenz:

- In the Lower Rhine area, fault-related subsidence is obvious in the Erft Basin, and farther toward the Northwest in the Rur Graben. Here, it reaches integral rates of about $6 \mathrm{~cm} \mathrm{ka}^{-1}$, i.e. about $50 \mathrm{~m}$ of height difference and even more in some places. This is obvious just close to the Erft Main Fault (Erft-Sprung). Block tilting took place in this area in an antithetical sense. The modern fault pattern follows the ancient pattern inherited since the Early Tertiary.

- The Neuwied Basin is limited by major faults in the north. Especially the Andernach Main Fault (Andernacher Sprung) in the NW is most evident, while the fault systems in the southern part are less 


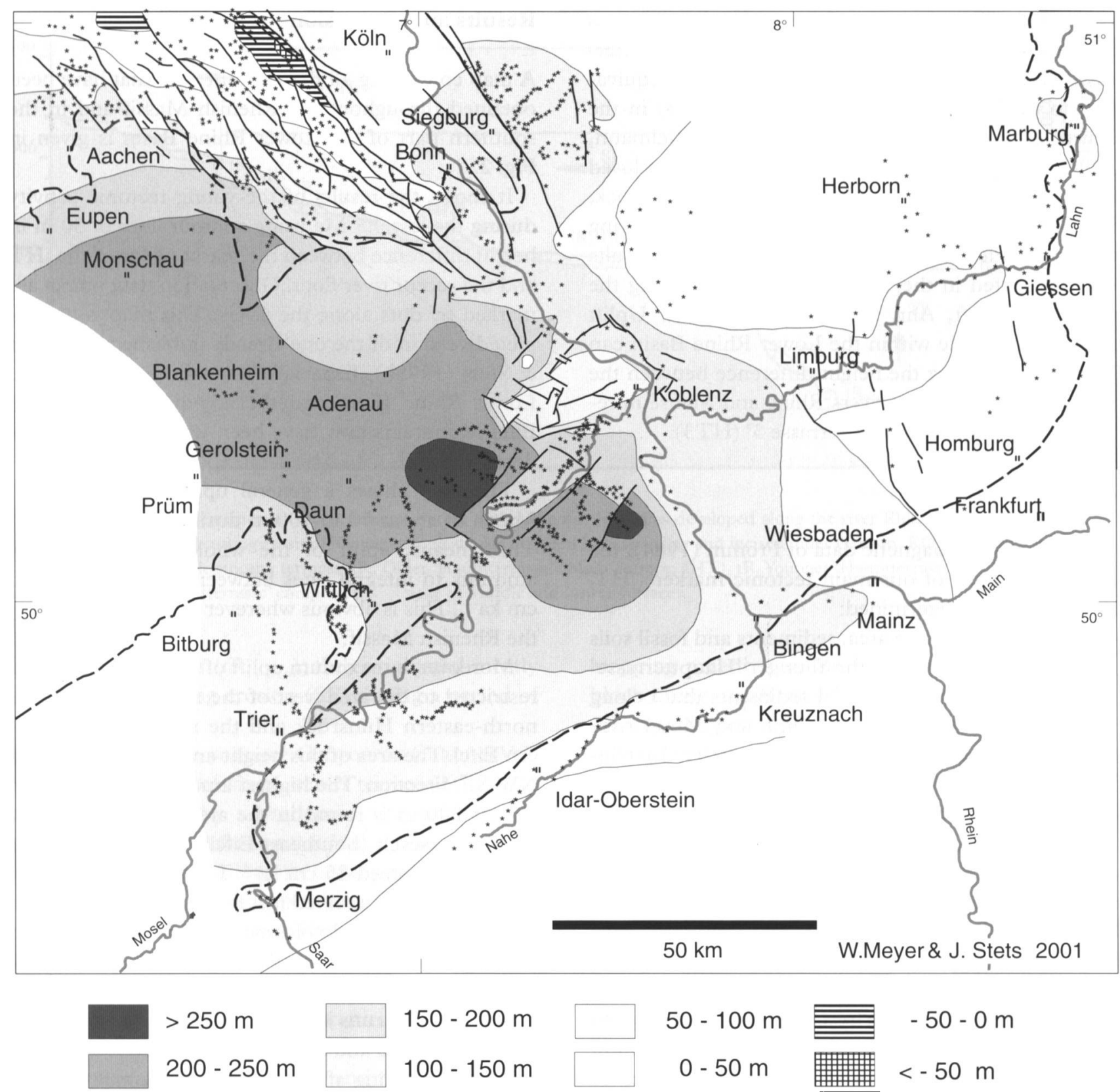

Fig. 2. Map showing the uplift of the Rhenish Massif during the last $0.8 \mathrm{Ma}$; contour lines illustrate $50 \mathrm{~m}$ in height difference of jHT level ('Jüngere Hauptterrasse') referred to the recent base level of the Rhine and Meuse river systems; observation data points are given as small dots along the rivers; the outer rim of the Massif is outlined by the dotted line.

remarkable. Uplift within this basin is only between 50 and $100 \mathrm{~m}$, corresponding to an integral uplift rate of $6-12 \mathrm{~cm} \mathrm{ka}^{-1}$. Thus, the uplift is reduced in the Neuwied Basin compared with the adjacent Eifel region in the west.

- In the Lower Mosel area SW of Koblenz, a NE-SW oriented graben structure crosses the domal uplift. Within this structure, the amount of uplift reaches only more than $150 \mathrm{~m}$, corresponding to an integral uplift rate of about 17 to $20 \mathrm{~cm} \mathrm{ka}^{-1}$. Here, the Pleistocene Mosel river changed its fluvial character from a meandering toward a braided river system.
Other major tectonic features of the Rhenish Massif, as for instance the Main Fault at its southern margin (Taunus-Hunsrück-Südrand-Verwerfung), the Wittlich Basin, the Idstein Graben, and the Limburg Basin are of no or only of minor influence. Moreover, there are many minor normal faults that do not exceed a downthrow of 5 to $10 \mathrm{~m}$ along the river long profiles. They are neglected in this map as they are of nearly no importance with respect to the main structure.

Coincidence exists between the area of modern uplift and parts of the relief in the Rhenish Massif. In the north-eastern Hunsrück area and in the Eifel region, altitudes of more than $600 \mathrm{~m}$ above sea level can 
be correlated with the area of maximum domal uplift, as has already been shown by Quitzow (1982) for the Eastern Eifel. In contrast, these high mountain ridges near to the southern margin of the Rhenish Massif (Taunuskamm, Hunsrück: Soonwald, Idar- and Hochwald) are ancient residual mountains. They protrude up to more than $800 \mathrm{~m}$ above sea level due to the resistance of the Lower Devonian Taunusquartzite which builds up the cores of these ridges.

\section{Conclusions}

Analysing the structural processes, which triggered the uplift described above, we have to distinguish between the uplift of the Rhenish Massif as a whole and the pronounced up-doming west of the river Rhine:

- The general uplift of the Rhenish Massif has to be seen under the auspices of the young tectonics of western Central Europe according to the ideas of Cloos (1939). He created the term 'Rhenish Shield' (Rheinischer Schild). Within this huge area that spreads far over the limits of the Rhenish Massif, long-term crustal movements controlled this uplift in context with the Alpine orogeny. It may even have started in the Late Jurassic and the Cretaceous. It was also controlled by isostatic compensation of denudation.

- With regard to this very young domal uplift in the eastern Hunsrück and in the Eifel, we have to look for other mechanisms, as for instance uplift in connection with a thermal anomaly in the Upper Mantle. We have to discuss this item in more detail when the results of the seismic Eifel Plume Project (Ritter, 1998) will have been presented. The two centres of young (Pleistocene) volcanism fit well to the area of maximum uplift in the Eifel region as does the distribution of mantle-derived volatiles documented by Griesshaber (1998).

Fault tectonics additionally affected this domal uplift at its north-eastern margin, inherited since the Paleogene (Lower Rhine Basin, Neuwied Basin). These two fault-bounded depressions have to be seen in connection with the large graben system running from the Upper Rhine Graben toward the North Sea.

\section{Acknowledgements}

We thank the German Science Foundation (DFG), Bonn-Bad Godesberg, for financial support of our team since 1991 in the scope of Project C2 of SFB 350 (Sonderforschungsbereich 350). Data from the Lahn, Middle Rhine and Mosel river systems were provided by Ploschenz (1994) and Hoffmann (1996). Still unpublished data from I. Stritzke and R. Zapp
(Bonn), have been used to improve our map in the area of the southern Lower Rhine Basin and in the adjoining areas east of it. $M$. Valdivia-Manchego (Bonn) prepared the computer-ready copy of fig. 2 . A. Siehl, A. Schäfer (Bonn), J. Grunert (Mainz), and R. Vinken (Hannover) reviewed a first draft of this paper and gave fruitful comments. Thanks are due to all of them.

\section{References}

Ahorner, L., 1962. Untersuchungen zur quartären Bruchtektonik in der Niederrheinischen Bucht. Eiszeitalter und Gegenwart 13: 24-105.

Cloos, H., 1939. Hebung - Spaltung - Vulkanismus; Elemente einer geometrischen Analyse irdischer Großformen. Geologische Rundschau 30: 401-527.

Fromm, K., 1987. Paläomagnetische Bestimmungen zur Korrelierung altpleistozäner Terrassen am Mittelrhein. Mainzer geowissenschaftliche Mitteilungen 16: 7-29.

Fuchs, K, von Gehlen, K., Mälzer, H., Murawski, H. \& Semmel, A. (eds), 1983. Plateau Uplift, The Rhenish Shield - a Case History. Springer (Heidelberg): $411 \mathrm{pp}$.

Griesshaber, E., 1998. The distribution pattern of mantle derived volatiles in mineral waters of the Rhenish Massif. In: Neugebauer, H.J., (ed.):Young Tectonics - Magmatism - Fluids, a Case Study of the Rhenish Massif, Publications of SFB 350, 74: 5159.

Hoffmann, R., 1996. Die quartäre Tektonik des südwestlichen Schiefergebirges begründet mit der Höhenlage der jüngeren Hauptterrasse der Mosel und ihrer Nebenflüsse. Bonner geowissenschaftliche Schriften 19: $156 \mathrm{pp}$.

Hoselmann, C., 1996. Der Hauptterrassen-Komplex am unteren Mittelrhein. Zeitschrift der Deutschen Geologischen Gesellschaft 147: 481-497.

Klostermann, J., 1992. Das Quartär der Niederrheinischen Bucht. Geologisches Landesamt Nordrhein-Westfalen (Krefeld): 200 pp.

Meyer, W. \& Stets, J., 1998a. Junge Tektonik im Rheinischen Schiefergebirge und ihre Quantifizierung. Zeitschrift der Deutschen Geologischen Gesellschaft 149: 359-379.

Meyer, W. \& Stets, J., 1998b. Young Pleistocene to Recent Uplift in the Rhenish Massif. In: Neugebauer, H.J., (ed.):Young Tectonics - Magmatism - Fluids, a Case Study of the Rhenish Massif, Publications of SFB 350, 74: 7-10.

Ploschenz, C., 1994. Quartäre Vertikaltektonik im südöstlichen Rheinischen Schiefergebirge begründet mit der Lage der Jüngeren Hauptterrasse. Bonner geowissenschaftliche Schriften 12: $185 \mathrm{pp}$.

Quitzow, H.W., 1982. Die Hochflächenlandschaft der zentralen Eifel und der angrenzenden Teile des Rhein-Troges und Neuwieder Beckens. Mainzer geowissenschaftliche Mitteilungen 11: 173-206.

Ritter, J.R.R., 1998. Imaging the Mantle under the Rhenish Massif: The Eifel Plume Project.- In: Neugebauer, H.J., (ed.): Young Tectonics - Magmatism - Fluids; a Case Study of the Rhenish Massif, Publications of SFB 350, 74: 91-95.

Schnütgen, A., 1974. Die Hauptterrassenfolge am linken Niederrhein aufgrund der Schotterpetrographie.- Forschungs-Berichte des Landes Nordrhein-Westfalen, 2399: $150 \mathrm{pp}$.

Spell, T.L. \& McDougall, I., 1992. Revisions to the Age of the BRUNHES / MATUYAMA Boundary and the Pleistocene Geomagnetic Polarity Timescale. Geophysical Research Letters 19: 1181-1184. 